\title{
The Effect of Thyroxine, the Antithyroid Drug Propylthiouracil and Thyroidectomy on Mineral Metabolism in Rat Tissues
}

\author{
By T. M. N. Al-Khayat, Th. M. Al-Darweesh and M. S. Islam \\ Department of Biochemistry, Medical College, University of Mosul, Iraq
}

(Received November 11, 1980/October 23, 1981)

Summary: The administration of thyroxine produces a significant increase in the copper, magnesium, iron and zinc contents of liver, with a concomitant decrease of heart iron. Magnesium in heart tissues was also increased.

The administration of antithyroid drugs produces a significant decrease in the concentration of the same metals in the liver with concomitant increases in kidney copper and calcium, and in heart magnesium and calcium.

Brain magnesium was found to be significantly decreased after antithyroid treatment and increased to a lesser extent after thyroxine administration.

Thyroidectomy did not produce an appreciable effect on minerals in various tissues, except heart zinc which was significantly decreased.

These findings suggested the involvement of thyroid hormones in tissue mineral metabolism, especially in the liver.

\section{Wirkung von Thyroxin, Propylthiouracil und Thyreoidektomie auf den Mineralstoffwechsel in Geweben der Ratte}

Zusammenfassung: Gabe von Thyroxin führt zu einem signifikanten Anstieg des Gehalts an Kupfer, Magnesium, Eisen und Zink in der Leber, begleitet von einem Abfall des Eisens im Herzen, während Magnesium im Herzen ebenfalls ansteigt.

Gabe antithyreoidal wirksamer Pharmaka führt zu einem signifikanten Abfall der Konzentration der genannten Metalle in der Leber, begleitet von Zunahmen des Kupfers und Calciums in der Niere sowie des Magnesiums und Calciums im Herzen.

Im Gehirn war Magnesium nach antithyreoiḍaler Behandlung signifikant vermindert und in einem geringeren Ausmaß vermehrt nach Thyroxingabe. Eine Thyreoidektomie führt zu keiner auffälligen Wirkung auf den Mineralgehalt der verschiedenen Gewebe, aụsgenommen eine signifikante Abnahme von Zink im Heržen.

Dieșe Befunde weisen auf eine Beteiligung von Schilddrüsenhormonen am Mineralstoffwechsel in Geweben, insbesondere der Leber, hin.

\section{Introduction}

Previous studies on the relationship between the state of the thyroid and the concentrations of metal ions in the serum and tissues provided minimal and sometimes contradictory information $(1-4)$.

Recent studies however showed that thyroid hormones effect the serum level of certain metals (for example, it was found that hyperthyroidism is associated with hypercalcaemia (5), increased plasma copper, decreased erythrocyte copper (6) and decreased serum magnesium (7).
Hypothyroidism was found to be associated with increased serum magnesium and decreased calcium excretion (7). These investigations demonstrated clearly the involvement of thyroid hormones in mineral metabolism in blood, but the possible role of these hormones in tissue mineral metabolism is not clear. The literature contains only a few relevant data; for example, Namikawa (8) demonstrated a clear increase of calcium and magnesium concentration in muscles of thyrotoxic patients; similarly Al-Khayat et al. (9) demonstrated a significant change in the mineral con- 
tents of thyroid gland in various diseases of thyroid glands associated with iodine deficiency. This stimulated us to investigate fully the effects of thyroxine, an antithyroid drug (propylthiouracil), and thyroidectomy on mineral metabolism in several key tissues (liver, kidney, heart and brain). The minerals chosen in this study were iron, copper, magnesium, calcium and zinc.

\section{Materials and Methods}

\section{Chemicals}

Chemicals of analar grade were used. Copper metal, zinc metal, and magnesium ribbon were purchased from Lab. Lachema chemicals. Hydrochloric acid and nitric acid were from RiedelDeHaen AG Hannover, iron metal from Hopkins and Williams Ltd., England, calcium carbonate from BDH Lab., England, and lanthanum from Fluka AG, Buchs S.G, Switzerland.

\section{Drugs}

Propylthiouracil (B.P.) was from Evans Ltd.; Company, sodiumL-thyroxine from Glaxo Lab., England, and Gum Acacia from Evans Ltd., Company.

\section{Experiments}

Forty eight male rats of the genus Sprague Dawley, from the animal house of the Medical College, Mosul University, were used for this study. They were fed a local mixed diet rich in proteins, and kept under hygienic conditions at a temperature not exceeding $35^{\circ} \mathrm{C}$.

The animals were divided into six groups:

Group I was used for total thyroidectomy, which was performed by a standard procedure, under anaesthesia (chloroform and ether).

Group II was used as a sham-control for group I. The animals of groups I and II were killed 21 days after the operation.

Group III was given antithyroid drug for 5 days.

Group IV was used as a control for group III and was kept under the same conditions. Groups III and IV were sacrificed after 15 days.

Group $V$ was given sodium $L$-thyroxine orally by stomach tube in a daily dose $54 \mu \mathrm{g} / \mathrm{kg}$ body weight/day for 7 days. The dose of thyroxine was calculated using the formulae of Paget \& Barnes (10).

Group VI was used as control for group V.

Groups V and VI were killed at the end of 7 days from the beginning of the experiment.

Serum was taken from each group before sacrifice, and the concentration of thyroxine determined by the method of Clark

\& Brown (11), using the Thyopac-4 Kit (Radiochemical Centre, Amersham, England). The livers, brains, hearts and kidneys were taken from each group, washed with saline, dried in an oven at $110^{\circ} \mathrm{C}$ for 48 hours, then weighed and ashed. The ashed samples were dissolved in $10 \mathrm{ml} 50 \mathrm{~g} / \mathrm{kg} \mathrm{HCl}$ and subjected to analysis for five minerals: copper, magnesium, iron, calcium and zinc, using the Perkin Elmer - 503 atomic absorption spectrophotometer according to the method of Boutwell (12) with the appropriate analytical conditions for each mineral.

Working standard solutions for all these minerals were prepared by diluting the metal stock solution $(1 \mathrm{~g} / \mathrm{l})$, which was prepared by dissolving $1 \mathrm{~g}$ of each metal or equivalent amounts of its salts in a minimum volume of acid $\left(\mathrm{HNO}_{3}\right.$ or $\left.\mathrm{HCl}\right)$ and subsequent dilution with water to one liter.

\section{Results}

Thyroxine concentrations were estimated in rat sera in order to determine the thyroidal state of the animals after various treatments (antithyroid drug, thyroxine administration or thyroidectomy). Table 1 shows the results of such estimations.

Table 2 shows the effects of thyroidectomy on the mineral contents of four rat organs, compared with their control vallues. It indicates that, in heart tissue, only zinc was significantly decreased after thyroidectomy.

Table 3 shows the effects of the antithyroid drug, propylthiouracil, on rat tissue minerals. It indicatês that the liver is the main organ affected by such treatment, and that magnesium, iron and calcium were decreased significantly in comparison with their normal control values in this organ.

Similarly, brain magnesium was found to be decreased after administration of the antithyroid drug. However, heart magnesium was significantly increased by such treatment. In addition, kidney copper and calcium were also increased.

The effects of thyroxine on mineräl metabolism in some tissues are illustrated in table 4. It is clear that liver copper, magnesium, iron and zinc were significantly increased. Heart magnesium showed a similar increase.

In contrast, heart iron was decreased significantly after administration of thyroxine.

Tab. 1. The mean values of serum thyroxine concentrations in various thyroidal conditions in comparison to their controls.

Sera of the rats from different groups were pooled before analyșis.

\begin{tabular}{|c|c|c|}
\hline Rat group & $\begin{array}{l}\text { No. of } \\
\text { rats }\end{array}$ & $\begin{array}{l}\text { Thyroxine } \\
\text { in serum } \\
(\mu \mathrm{g} / \mathrm{l})\end{array}$ \\
\hline $\begin{array}{l}\text { Thyroidectomy (Group I) } \\
\text { Sham or control (Group II) }\end{array}$ & $\begin{array}{l}8 \\
8\end{array}$ & $\begin{array}{l}11.63 \\
33.50\end{array}$ \\
\hline $\begin{array}{l}\text { Antithyroid-treated (Group III) } \\
\text { Control (Group IV) }\end{array}$ & $\begin{array}{l}8 \\
8\end{array}$ & $\begin{array}{l}25.12 \\
49.62\end{array}$ \\
\hline $\begin{array}{l}\text { Thyroxine-treated (Group V) } \\
\text { Control (Group VI) }\end{array}$ & $\begin{array}{l}8 \\
8\end{array}$ & $\begin{array}{l}77.25 \\
43.25\end{array}$ \\
\hline
\end{tabular}

Groups $I$ and III found to have low serum thyroxine concentration. Group $\mathrm{V}$ shows high serum thyraxine concentration. 
Tab. 2. The mean values \pm S.D. for certain mineral contents in various organs of thyroidectomized rats with their controls. The mean values were expressed in $\mathrm{mmol} / \mathrm{kg}$ dry weight of rat tissue, d.f. $=14$.

\begin{tabular}{|c|c|c|c|c|c|c|}
\hline Organ & $\begin{array}{l}\text { Group II } \\
\text { and I }\end{array}$ & $\mathrm{Cu}^{2+}$ & $\mathrm{Mg}^{2+}$ & $\mathrm{Fe}^{3+}$ & $\mathrm{Ca}^{2+}$ & $\mathrm{Zn}^{2+}$ \\
\hline \multirow[t]{2}{*}{ Liver } & Control & $\begin{array}{r}0.19 \\
\pm 0.01\end{array}$ & $\begin{array}{r}45.3 \\
+\quad 4.9\end{array}$ & $\begin{array}{r}7.2 \\
\pm \quad 0.9\end{array}$ & $\begin{array}{r}0.28 \\
\pm 0.05\end{array}$ & $\begin{array}{r}1.5 \\
\pm 0.1\end{array}$ \\
\hline & Treatment & $\begin{array}{l}0.2 \\
\pm 0.02\end{array}$ & $\begin{array}{r}44.7 \\
\pm \quad 4.9\end{array}$ & $\begin{array}{r}8.7 \\
\pm \quad 1.6\end{array}$ & $\begin{array}{r}0.27 \\
\pm 0.06\end{array}$ & $\begin{array}{r}1.5 \\
\pm 0.3\end{array}$ \\
\hline $\mathbf{p}$ & & NS & NS & NS & NS & NS \\
\hline \multirow[t]{2}{*}{ Brain } & Control & $\begin{aligned} & 0.2 \\
\pm & 0.01\end{aligned}$ & $\begin{array}{r}36.9 \\
\pm \quad 2.2\end{array}$ & $\begin{array}{r}11.6 \\
\pm \quad 2.9\end{array}$ & $\begin{aligned} & 0.65 \\
\pm & 0.1\end{aligned}$ & $\begin{array}{r}2.8 \\
\pm 0.2\end{array}$ \\
\hline & Treatment & 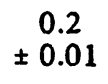 & $\begin{array}{r}35.3 \\
\pm \quad 1.2\end{array}$ & $\begin{array}{r}10.7 \\
\pm \quad 2.9\end{array}$ & $\begin{aligned} & 0.5 \\
\pm & 0.09\end{aligned}$ & $\begin{array}{r}3.0 \\
\pm 0.2\end{array}$ \\
\hline $\mathbf{p}$ & & NS & NS & NS & NS & NS \\
\hline \multirow[t]{2}{*}{ Heart } & Control & 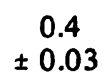 & $\begin{array}{r}74.3 \\
\pm \quad 6.8\end{array}$ & $\begin{array}{r}17.0 \\
\pm \quad 2.0\end{array}$ & $\begin{array}{r}4.3 \\
\pm 0.7\end{array}$ & $\begin{array}{r}5.3 \\
\pm 0.7\end{array}$ \\
\hline & Treatment & $\begin{array}{c}0.4 \\
\pm 0.02\end{array}$ & $\begin{array}{r}64.2 \\
\pm \quad 9.6\end{array}$ & $\begin{array}{r}16.7 \\
\pm \quad 3.9\end{array}$ & $\begin{array}{r}4.5 \\
\pm 0.5\end{array}$ & $\begin{array}{r}4.2 \\
\pm 0.2\end{array}$ \\
\hline p & & NS & NS & NS & NS & $<0.05$ \\
\hline \multirow[t]{2}{*}{ Kidney } & Control & $\begin{aligned} & 0.3 \\
\pm & 0.03\end{aligned}$ & $\begin{array}{r}31.8 \\
\pm \quad 2.6\end{array}$ & $\begin{array}{r}20.5 \\
\pm \quad 4.3\end{array}$ & $\begin{array}{r}0.9 \\
\pm 0.2\end{array}$ & $\begin{array}{r}3.6 \\
\pm 0.6\end{array}$ \\
\hline & Treatment & $\begin{array}{c}0.4 \\
\pm 0.04\end{array}$ & $\begin{array}{r}35.5^{\circ} \\
\pm \quad 1.6\end{array}$ & $\begin{array}{r}16.8 \\
\pm \quad 1.9\end{array}$ & $\begin{array}{r}0.9 \\
\pm 0.2\end{array}$ & 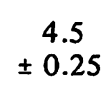 \\
\hline $\mathbf{p}$ & & NS & NS & NS & NS & NS \\
\hline
\end{tabular}

Tab. 3. The mean values \pm S.D. for certain mineral contents in various organs of rats given antithyroid drug, compared with their controls.

The mean values were expressed in $\mathrm{mmol} / \mathrm{kg}$ dry weight of rat tissue, d.f. $=14$.

\begin{tabular}{|c|c|c|c|c|c|c|}
\hline Organ & $\begin{array}{l}\text { Group IV } \\
\text { and III }\end{array}$ & $\mathrm{Cu}^{2+}$ & $\mathrm{Mg}^{2+}$ & $\mathrm{Fe}^{3+}$ & $\mathrm{Ca}^{2+}$ & $\mathrm{Zn}^{2+}$ \\
\hline \multirow[t]{2}{*}{ Liver } & Control & $\begin{array}{r}0.18 \\
\pm 0.01\end{array}$ & $\begin{array}{r}37.3 \\
+\quad 4.0\end{array}$ & $\begin{array}{r}6.8 \\
\pm \quad 0.8\end{array}$ & $\begin{array}{r}0.22 \\
\pm 0.02\end{array}$ & 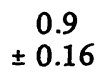 \\
\hline & Treatment & $\begin{array}{r}0.14 \\
\pm 0.01\end{array}$ & $\begin{array}{r}27.9 \\
\pm \quad 2.03\end{array}$ & $\begin{array}{r}3.9 \\
\pm \quad 0.6\end{array}$ & $\begin{array}{r}0.12 \\
\pm 0.01\end{array}$ & $\begin{array}{r}0.8 \\
\pm 0.1\end{array}$ \\
\hline $\mathbf{p}$ & & NS & $<0.05$ & $<0.05$ & $<0.05$ & NS \\
\hline \multirow[t]{2}{*}{ Brain } & Control & $\begin{array}{c}0.3 \\
\pm 0.03\end{array}$ & $\begin{array}{r}47.5 \\
\pm \quad 7.7\end{array}$ & $\begin{array}{r}11.1 \\
\pm \quad 1.7\end{array}$ & $\begin{array}{r}2.6 \\
\pm 0.6\end{array}$ & $\begin{array}{c}2.4 \\
\pm 0.15\end{array}$ \\
\hline & Treatment & $\begin{array}{c}0.3 \\
\pm 0.03\end{array}$ & $\begin{array}{r}27.1 \\
\pm \quad 2.3\end{array}$ & $\begin{array}{r}9.8 \\
\pm \quad 1.4\end{array}$ & $\begin{array}{r}3.2 \\
\pm 0.8\end{array}$ & $\begin{array}{c}2.2 \\
\pm 0.16\end{array}$ \\
\hline p. & & NS & $<0.001$ & NS & NS & NS \\
\hline \multirow[t]{2}{*}{ Heart } & Control & $\begin{array}{l}0.4 \\
\pm 0.02\end{array}$ & $\begin{array}{r}27.4 \\
\pm \quad 1.0\end{array}$ & $\begin{array}{r}11.6 \\
\pm \quad 0.8\end{array}$ & $\begin{array}{r}3.0 \\
\pm 0.4\end{array}$ & $\begin{array}{r}3.6 \\
\pm 0.4\end{array}$ \\
\hline & Treatment & $\begin{array}{c}0.5 \\
\pm 0.05\end{array}$ & $\begin{array}{r}35.7 \\
\pm \quad 2.3\end{array}$ & $\begin{array}{r}13.8 \\
\pm \quad 1.9\end{array}$ & $\begin{array}{c}5.3 \\
\pm 0.62\end{array}$ & $\begin{array}{r}2.7 \\
\pm 0.3\end{array}$ \\
\hline $\mathbf{p}$ & & NS & $<0.01$ & NS & $<0.05$ & NS \\
\hline \multirow[t]{2}{*}{ Kidney } & Control & 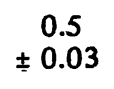 & $\begin{array}{r}33.5 \\
\pm \quad 2.6\end{array}$ & $\begin{array}{r}11.0 \\
\pm \quad 0.7\end{array}$ & $\begin{array}{l}0.5 \\
\pm 0.06\end{array}$ & $\begin{array}{ll} & 3.05 \\
\pm & 0.3\end{array}$ \\
\hline & Treatment & 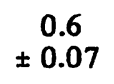 & $\begin{array}{r}45.1 \\
\pm 11.0\end{array}$ & $\begin{array}{r}9.4 \\
\pm \quad 0.7\end{array}$ & $\begin{array}{ll} & 1.9 \\
\pm & 0.36\end{array}$ & $\begin{array}{r}3.27 \\
\pm 0.25\end{array}$ \\
\hline $\mathbf{p}$ & & $<0.05$ & NS & NS & $<0.05$ & NS \\
\hline
\end{tabular}


Tab. 4. The mean values \pm S.D. for certain mineral contents in various organs of rats given thyroxine to induce hyperthyroidism, compared with their controls.

The mean values were expressed in $\mathrm{mmol} / \mathrm{kg}$ dry weight of rat tissue, d.f. $=14$.

\begin{tabular}{|c|c|c|c|c|c|c|}
\hline Organ & $\begin{array}{l}\text { Group VI } \\
\text { and V }\end{array}$ & $\mathrm{Cu}^{2+}$ & $\mathrm{Mg}^{2+}$ & $\mathrm{Fe}^{3+}$ & $\mathrm{Ca}^{2+}$ & $\mathrm{Zn}^{2+}$ \\
\hline \multirow[t]{2}{*}{ Liver } & Control & $\begin{aligned} & 0.153 \\
\pm & 0.01\end{aligned}$ & $\begin{array}{r}39.3 \\
\pm \quad 3.9\end{array}$ & $\begin{array}{r}5.7 \\
\pm \quad 0.8\end{array}$ & $\begin{array}{r}0.18^{\prime} \\
\pm 0.03\end{array}$ & $\begin{array}{r}0.88 \\
\pm 0.05\end{array}$ \\
\hline & Treatment & $\begin{array}{c}0.2 \\
\pm 0.008\end{array}$ & $\begin{array}{r}47.5 \\
\pm \quad 3.2\end{array}$ & $\begin{array}{r}9.7 \\
\pm \quad 0.6\end{array}$ & $\begin{array}{r}0.14 \\
\pm 0.01\end{array}$ & $\begin{array}{c}1.4 \\
\pm 0.07\end{array}$ \\
\hline p & & $<0.001$ & $<0.05$ & $<0.05$ & NS & $<0.001$ \\
\hline \multirow[t]{2}{*}{ Brain } & Control & $\begin{array}{c}0.3 \\
\pm 0.04\end{array}$ & $\begin{array}{r}43.0 \\
\pm \quad 4.6\end{array}$ & $\begin{array}{ll} & 7.17 \\
\pm & 0.8\end{array}$ & $\begin{aligned} & 2.66 \\
\pm & 0.6\end{aligned}$ & $\begin{array}{r}3.16 \\
\pm 0.24\end{array}$ \\
\hline & Treatment & $\begin{array}{r}0.26 \\
\pm 0.03\end{array}$ & $\begin{array}{r}44.5 \\
\pm \quad 4.5\end{array}$ & $\begin{array}{r}10.6 \\
\pm \quad 1.9\end{array}$ & $\begin{array}{r}1.96 \\
\pm \quad 0.4\end{array}$ & $\begin{array}{r}3.0 \\
\pm 0.2\end{array}$ \\
\hline p & & NS & NS & NS & NS & NS \\
\hline \multirow[t]{2}{*}{ Heart } & Control & $\begin{array}{r}0.43 \\
\pm 0.05\end{array}$ & $\begin{array}{r}32.3 \\
\pm \quad 4.5\end{array}$ & $\begin{array}{r}27.9 \\
\pm \quad 3.7\end{array}$ & $\begin{array}{r}3.0 \\
\pm 0.7\end{array}$ & $\begin{array}{l}3.84 \\
\pm 0.4\end{array}$ \\
\hline & Treatment & $\begin{array}{r}0.43 \\
\pm 0.04\end{array}$ & $\begin{array}{r}63.8 \\
+16.3\end{array}$ & $\begin{array}{r}16.3 \\
\pm \quad 1.8\end{array}$ & $\begin{array}{r}2.9 \\
\pm 0.5\end{array}$ & $\begin{array}{l}3.85 \\
\pm 0.2\end{array}$ \\
\hline p & & NS & $<0.05$ & $<0.01$ & NS & NS \\
\hline \multirow[t]{2}{*}{ Kidney } & Control & $\begin{array}{r}0.36 \\
\pm 0.01\end{array}$ & $\begin{array}{r}28.9 \\
\pm \quad 1.4\end{array}$ & $\begin{array}{r}16.5 \\
\pm \quad 2.3\end{array}$ & $\begin{array}{r}0.5 \\
\pm 0.1\end{array}$ & $\begin{array}{ll} & 2.97 \\
\pm & 0.2\end{array}$ \\
\hline & Treatment & $\begin{array}{r}0.39 \\
\pm 0.08\end{array}$ & $\begin{array}{r}27.9 \\
+\quad 3.9\end{array}$ & $\begin{array}{r}13.3 \\
\pm \quad 1.5\end{array}$ & $\begin{array}{c}0.4 \\
\pm 0.09\end{array}$ & $\begin{array}{ll} & 3.35 \\
\pm & 0.1\end{array}$ \\
\hline p & & NS & NS & NS & NS & NS \\
\hline
\end{tabular}

\section{Discussion}

The results of this study demonstrate that the administration of thyroxine to experimental rats for 7 days produces a significant increase in the copper, magnesium, iron and zinc contents of the liver (tab. 4).

Similarly, heart magnesium was significantly increased after thyroxine administration; brain magnesium wạs also increased, but to a lesser extent.

The administration of antithyroid drug to rats produced a significant decrease in the concentration of the above metals in the liver. Brain magnesium was also decreased after such treatment (tab. 3).

It has now been established that the low molecular weight protein, metallothionein, plays an important regulatory role in the metabolism of zinc, particularly in the control of intestinal absorption and hepatic uptake of the metal $(13,15)$.

The administration of zinc salts to animals also causes the synthesis of the hepatic zinc protein, metallothionein (14).

Similarly, the injection of copper salts into rats stimulates the production of copper binding protein of molecular weight around 12,000 (copper-chelatin) $(16,17$,
Calcium binding protein has been identified in the gut, kidney, and egg shell gland (19). It was suggested that this calcium binding protein may be involved in trans: cellular transport and/or storage of calcium.

According to the so-called "mucosal block" theory, the amount of iron binding protein, apoferritin, in the mucosal cells is the controlling factor in the absorption of iron by the intestine itself, and normally the apoferritin content of the mucosal cells is low. But there is evidence for a rapid increase in its formation by intestinal mucosal cells as a result of the administration of iron (20).

From all the previous data, it is possible to deduce that administration of certain metals like zince, copper, and iron, may induce the synthesis of their corresponding metal binding proteins.

Therefore, the increase in the concentration of copper, zinc and possibly iron in the liver, after the administration of these metals, is probably associated with the increase in the synthesis of their corresponding metal binding protein.

Thyroxine was found to induce the formation and synthesis of certain enzyme proteins like FAD-linked dehydrogenenàses. .$i$ 
A binding site for the thyroid hormones has been demonstrated in the cell nucleus, suggesting that these hormones probably regulate nuclear transcription (21).

Similarly, Tata \& Windell (22) found that after the administration of thyroid hormone to hypothyroid rats, there was a stimulation of magnesium-dependent ribosomal RNA polymerase which also indicates the involvement of thyroxine in protein biosynthesis.

Recently, Soli et al. (23) demonstrated that certain chelating agents have the property of mobilizing heavy metals, like copper, in sheep. Thyroxine, which can easily be chelated with copper (24), could play a role in the mobilization of heavy metals like copper in the body to the liver, since thyroid hormones are removed from circulation primarily by the liver (21).

The changes in the concentrations of these different metals in various organs other than liver and brain in hypo- and hyperthyroid states, follow different patterns which cannot be easily explained, presumably because other factors are involved.

Thyroidectomy itself did not produce appreciable effects on mineral metabolism. This indicates that normally parathyroid hormone and/or calcitonin, probably play an important role in the metabolism of tissue minerals, especially in the liver, where they presumably oppose the action of thyroxine on mineral metabolism. Our suggestion that parathyroid hormones are involved in mineral metabolism is confirmed by recent studies (25). These studies clearly demonstrated that parathyroid hormone effects the absorption of magnesium from the intestine, and it was found that hyperthyroidism is associated with a decreased serum magnesium level (26). However, the mechanism of action of these hormones seems to be very complicated, and to our knowledge we have demonstrated for the first time, the role of thyroxine in mineral metabolism in the body.

In conclusion, this study revealed that mineral metabolism is more complex than hitherto known, and involves several hormones. This study demonstrated clearly that thyroid hormones directly or indirectly affect the metabolism of tissue minerals, especially in the liver.

\section{Acknowledgement}

The authors express their gratitude to Dr. Maher Taka, Head of the Statistics Department, Science College, for his help in statistical analysis of the work.

\section{References}

1. Locke, A. E., Main, E. R. \& Rosbash, D. O. (1932) J. Clin. Invest. $11,527-542$.

2. Gubler, C. J., Lahey, M. E., Cartwright, G. E. \& Wintrobe, M. M. (1953) J. Clin. Invest. 32, 405-414.

3. Meyer, B. J., Meyer, A. C. \& Horwitt, M. K. (1959) Arch. Gen. Psychiat. 1, 372-378.

4. Evans, G. W. \& Wiederanders, R. E. (1968) Am. J. Physiol. 214, 1152-1154.

5. Burman, K. D., Monchik, J. M., Earl, J. M. \& Wartofsky, L. (1976) Ann. Intern. Med. 84, 668-671.

6. Sonnenwirth, A. \& Jarett, L. (1980) Gradwohls Clinical Laboratory Methods and Diagnosis, 1, 379-381. Publisher, The C. V. Mosby Company, St. Louis, Toronto, London.

7. Wallach, J. (1974) Interpretation of diagnostic test. 2 nd. Ed. Publ. Little, Brown, Boston.

8. Namikawa, M. (1970) J. Med. Soc. Tokyo Univ. 17, 50-53.

9. Al-Khayat, T. M. N., Al-Darweesh, T. H., \& Taka, M. (1980) Ann. Coll. Med. Mosul. 11, 81-86.

1.0. Paget, G. E. \& Barnes, J. M. (1964) Evbluation of drug activities. Publ. Academic Press. London, New York.

11. Clark, F. \& Brown, H. (1970) British Med. J. $1,713=715$.

12. Boutwell, J. H. (1961); Clinical Chemistry Laboratory Manual and Methods. 95-99. Publ.. London.

13. Bremner, I., \& Davies, T. N. (1975) Biochem. J. 149 , 733-738.

14. Richards, M. P. \& Cousins, R. J. (1975) Bioinorg. Chem. 4, 215-224.

15. Richards, M. P. \& Cousins, R. J. (1976) J. Nutr. 106, $1591-1599$.

16. Boomer, L. C. \& Sourkes, T. L. (1973) Biochem. Med. 9 , 78-91.

17. Bremner, I. (1974) Quart. Rev. Biophys. 7, 75-124.

18. Winge, D. R., Premakumar, R., Wiley, R. D. \& Rajagopalan, K. V. (1975) Arch. Biochem. Biophys. 170, 253-266.

19. Kretsinger, R. H. (1976) Ann. Rev. Biochem. 45, 239-266.

20. Harper, $\ddot{H}$. A. (1975) A Review of Physiological Chemistry. 15th. Ed., 439-440. Publ. Lange Medical Publications. Los Altos, California.

21. Montgomery, R., Dryer, R. L., Conway, T. W. \& Spector, A. A. (1977) Biochemistry, A case oriented approach, 2nd. Ed. 631-633. Publ. C. V. Mosby Comp. St. Louis. Toronto, London.

22. Tata, J. R. \& Windell, C. C. (1966) Biochem. J. 98, 604-620.

23. Soli, N. E., Francis, A. \& Asseth, J. (1978) Acta Vet. Scand., $19,422-426$.

24. Frieden, E. (1962) Horizons in biochemistry (Kasha, M. \& Pullman, B., eds.) 492-495. Publ. Acad. Press. New York, London.

25. Meclintic, J. R. (1978) Physiology of human body, 2nd. Ed., 522-523. Publ. John Wiley and Sons. New York.

26. Harper, H. A., Rodwell V. W. \& Mayes, P. A. (1979) Review of physiological chemistry, 17th. Ed. 578-579. Publ. Lange Medical Publications.

Dr. Talal M. N. Al-Khayat Department of Biochemistry College of Medicine University of Mosul Mosul

Iraq 
